\title{
Evaluating the State of Nature through Gameplay
}

\author{
RYAN POLLOCK \\ Pennsylvania State University
}

\begin{abstract}
In this paper I present an in-class game designed to simulate the state of nature. I first explain the mechanics of the game, and how to administer it in the classroom. Then I address how the game can help introduce students to a number of important topics in political philosophy. In broad terms, the game serves to generate discussion regarding two main questions. (1) How does civil society come about? (2) Is the state of nature and the arrangement which arises from it fair? In so doing I suggest how the game can further student understanding of figures such as Aristotle, Hobbes, Locke, Hume, Rousseau, Marx, and Rawls.
\end{abstract}

Philosophical accounts of the "state of nature" provide an excellent opportunity for philosophy instructors who wish to utilize interactive classroom activities. A number of others have demonstrated this by developing games and role playing exercises designed to illustrate the state of nature. ${ }^{1}$ In this paper I will add to the current repertoire of such exercises with my own game designed to help students evaluate and understand the move from the state of nature to civil society. In doing so I will first provide a quick review of existing state of nature games, and outline what is novel about my game. Next I will explain the game's rules and how to effectively facilitate the activity in class. Finally, I will discuss the game's philosophical import and how it can be used in a historically-based political philosophy course.

\section{Existing State of Nature Activities}

Perhaps the first classroom game of this type is John Immerwahr's "The Hobbes Game," which introduces students to the state of nature by pitting them against one another in "prisoner's dilemma"-style conflict with the presumption that their course grades are at stake. ${ }^{2}$ This type of exercise is extremely useful for demonstrating Hobbes's 
claim that it is in one's rational self-interest to make sacrifices for the sake of greater security. The reason for this is that the game employs clearly defined rules and unambiguous standards for what constitutes success and failure. With these rules in place students can clearly understand the risks and rewards associated with their choices. However, one of my goals was to have the students interact with one another from unequal starting points and from a unique point of view. All of the participants in Immerwahr's game begin (as Hobbes says they do) in a state of equality, and thus I began exploring ways to introduce differentiation among the participants. ${ }^{3}$

This led me to examine the Hobbesian state of nature role-playing exercise developed by Christina M. Bellon. ${ }^{4}$ In this activity each participant is assigned a character with differing abilities, resources, and psychological dispositions. The students are then instructed to share their character with the other players and to take on that particular identity. When play begins students collectively work out (within broad constraints) whether or not they will enter civil society. With the introduction of characters it is possible to achieve the differentiation among players which is not possible in games which focus solely on the prisoner's dilemma aspect of the state of nature. Yet, in this particular exercise what is lost is the ability for the student to feel the full force of his/her trade-offs. While players are given the general stipulation that resources are scarce, the quantity of each resource is not strictly defined. However, although this was not Bellon's particular goal in constructing her role-playing exercise ${ }^{5} \mathrm{I}$ wanted the game to preserve the competitive aspect that was so prevalent in Immerwahr's game. This requires students to be acutely aware of just how scarce resources are, so that the risks and rewards of their decisions are fully understood.

Given the advantages I saw in each of these classroom activities I wanted to see if there was a way to combine them. My goal was to develop a game in which participants took on the role of a certain character, with differing resources and abilities, and engaged others in prisoners dilemma-type conditions. In the following I will outline the rules for playing the game which I developed for this purpose, followed by a discussion of its pedagogical import.

\section{Game Materials}

(1) At least ten players.

Each game requires at least ten players, but it is possible to accommodate more, if necessary. Generally my classes have somewhere between twenty and thirty students, and so I come prepared to have three separate games, but usually split the class up into two groups with some students partnering together with one character. For instance, in a 
class of twenty-two students, I would split the students into groups of eleven. Then nine of the students in each group would have a character to themselves while the remaining two would share the last character.

(2) Eighty-one resource cards divided in the following manner: four Apple Cards, four Bread Cards, two Cow Cards, ten Water Access Cards, eighteen Lumber Cards, eighteen Spear Cards, nine House Cards, ten Freedom Cards (each freedom card should bear the name of whose freedom it is, e.g., Rowdy Rachel's Freedom, see below for description of characters), one Church Card, two Church Residence Cards, one Bakery Card, one Bakery Employment Card, and one Water Well Card.

The resource cards represent each of the items in the game and are transferred as players perform different actions. To make these cards I have typed out the name of the resource on plain white paper (e.g., "Apple," "Church," or "Lumber"), taped that to a rectangular piece of colored construction paper, and then laminated it with contact paper. A simpler, although less durable, manner of making these cards is simply to print them out on plain white paper without any lamination.

(3) Ten plastic bags containing the particular allotment of resources for each player.

As we will see shortly, the game has ten different characters, all of which begin the game in possession of different resources and abilities. To make the initial distribution of resources easy, I will have one plastic bag labeled with each character's name and filled with the specific resource cards allotted to that player.

(4) Ten name tags (one for each character).

It is important that the players can identify the other characters in the game, so in every character's bag there should also be a name tag which makes this clearly visible to all other players.

(5) Ten character cards (one for each character).

In each character's plastic bag there should be a printed-out piece of paper which describes the character and lists his/her starting resources and abilities. Each of the ten character cards are displayed below. Some of these characters are inspired by Bellon's role-playing exercise, while others are completely original.

\footnotetext{
Sawmill Sam: A grizzly old man who has only one hand as a result of a sawing accident. Loves nothing more than cutting down trees and laying waste to nature.

Abilities

- Starting Attack Rating: 1

Starting Resources

- Sawmill Sam's Freedom Card

- 18 Lumber Cards
} 
Ronnie Appleseed: A kindly chap who loves to see the flourishing bounty of nature. Owns a stock of apples picked delicately from his beloved trees.

Abilities

- Starting Attack Rating: 1

Starting Resources

- Ronnie Appleseed's Freedom Card

- 4 Apple Cards

Wet Willy: Wet Willy's words are as slick as the water which runs through his well.

Abilities

- Starting Attack Rating: 1

Starting Resources

- Wet Willy's Freedom Card

- Water Well Card (which gives owner 10 water access cards)

St. Bernard: A pacifist religious leader who owns the church.

Abilities

- Starting Attack Rating: 0

- Not allowed to increase attack rating by possessing a spear.

Starting Resources

- St. Bernard's Freedom Card

- Church Card (which gives owner shelter and 2 Church Residence Cards)

Baker Bettie: Sister of Blacksmith Betty and a former baker who is currently captive of Alexandra the Great.

Abilities

- Starting Attack Rating: 1

- Ability to become employed as a baker at a bakery.

Starting Resources

- None

Alexandra the Great: A feared warrior with a mean streak who will not hesitate to slay any foe. Currently holding Baker Bettie in captivity.

Abilities

- Starting Attack Rating: 4

Starting Resources

- Alexandra the Great's Freedom Card

- Baker Bettie's Freedom Card

Nefarious Ned: A shifty character who is a skilled thief and capable fighter. Spends most of his time in dark corners waiting to strike.

Abilities

- Starting Attack Rating: 2

Starting Resources

- Nefarious Ned's Freedom Card 
Blacksmith Betty: Sister of Baker Bettie and the local blacksmith, has the ability to convert lumber into spears.

Abilities

- Starting Attack Rating: 1

- Ability to make spears with one Lumber Card.

Resources

- Blacksmith Betty's Freedom Card

Bertha the Builder: An intelligent, efficient architect and skilled builder who excels at construction.

Abilities

- Starting Attack Rating: 1

- Ability to build the Bakery with 4 Lumber Cards.

Starting Resources

- Bertha the Builder's Freedom Card

Rowdy Rachel: A local rancher who loves to stir up a ruckus.

Abilities

- Starting Attack Rating: 1

Starting Resources

- Rowdy Rachel's Freedom Card

2 Cow Cards

(6) One plastic bag labeled "Undistributed Items," and one plastic bag labeled "Used Items."

Some of the game's items will not be in anyone's possession at the outset and these should be placed in the Undistributed Items bag. The following items should be placed in this bag: eighteen Spear Cards, nine House Cards, four Bread Cards, one Bakery Card, and one Bakery Employment Card. The Used Items bag is empty at the beginning of the game but as the game progresses when certain items are used they are placed in that bag.

Once all these materials have been compiled, and put into the correct plastic bags, I put all twelve plastic bags (one bag for each of the ten characters, the Undistributed Items bag, and the Used Items bag) in one manila envelope to facilitate easy transportation and distribution to students. On the day of the game, after dividing the class into groups where all players are facing one another, I tell them to pass around the manila envelope and randomly draw out one of the bags. This determines the character they will represent in the game. I then give the Undistributed Items and Used Items bags to whoever has the character of St. Bernard. This player will be in charge of these bags throughout the game, playing the same role as the banker in Monopoly. I also remind everyone to display their character's name tag in a place easily visible to the other players. 


\section{Resource Descriptions}

After all the students have been divided into groups and assigned their characters I then explain the rules of the game, beginning with a description of each of the items in the game. The table below provides a description of what function each item has.

\begin{tabular}{|c|c|}
\hline Resource & Purpose \\
\hline Apples & $\begin{array}{l}\text { Ownership of one Apple Card fully satisfies a player's need } \\
\text { for food. }\end{array}$ \\
\hline Bread & $\begin{array}{l}\text { Ownership of one Bread Card fully satisfies a player's need } \\
\text { for food. }\end{array}$ \\
\hline Cows & $\begin{array}{l}\text { Ownership of one Cow Card fully satisfies a player's need } \\
\text { for food. }\end{array}$ \\
\hline Water Access & $\begin{array}{l}\text { Ownership of one Water Access Card fully satisfies a player's } \\
\text { need for water. }\end{array}$ \\
\hline Lumber & $\begin{array}{l}\text { Lumber is used to construct spears, houses, and the bakery } \\
\text { (see below for a description of these items). One Lumber Card } \\
\text { is needed to construct a spear (and can only be built by Black- } \\
\text { smith Betty), two Lumber Cards to construct a house (and can } \\
\text { be built by anyone), and four Lumber Cards to construct the } \\
\text { bakery (and can only be built by Bertha the Builder). Once } \\
\text { a lumber card is used it is placed in the "Used Items" bag. }\end{array}$ \\
\hline Spears & $\begin{array}{l}\text { Ownership of a Spear Card increases a player's attack rating } \\
\text { by } 1 \text {, requires one lumber card to be built, and can only be } \\
\text { built by Blacksmith Betty. While a player may own as many } \\
\text { spears as s/he pleases that player's attack rating can only be } \\
\text { increased once. }\end{array}$ \\
\hline Freedom & $\begin{array}{l}\text { At the beginning of the game every player is given one Free- } \\
\text { dom Card to represent their freedom (except for Baker Bettie } \\
\text { who begins the game as a captive of Alexandra the Great). If } \\
\text { a player is taken captive then his/her Freedom Card will go } \\
\text { to the player who captured him/her, representing their loss } \\
\text { of freedom. See the following section for rules pertaining to } \\
\text { captivity, and escaping captivity. }\end{array}$ \\
\hline Houses & $\begin{array}{l}\text { Ownership of one House Card satisfies a player's need for } \\
\text { shelter. A house can be built, by any player, with two lumber } \\
\text { cards. Only one person can live in a house at one time. }\end{array}$ \\
\hline Church & $\begin{array}{l}\text { Control of the church gives the owner shelter and gives the } \\
\text { owner two Church Residence Cards. }\end{array}$ \\
\hline Church Residence & $\begin{array}{l}\text { When the owner of the church allows a player to live in the } \\
\text { church he or she receives a Church Residence Card. Posses- } \\
\text { sion of this card fulfills one's need for shelter. }\end{array}$ \\
\hline Bakery & $\begin{array}{l}\text { The Bakery requires four Lumber Cards to be built, and can } \\
\text { only be built by Bertha the Builder. Only one bakery may } \\
\text { be made during the course of the game. After the bakery has } \\
\text { been built the owner must hire Baker Bettie to work there } \\
\text { in order for it to produce bread. The person who owns the } \\
\text { bakery at the time when baker Bettie is hired will receive } \\
\text { four Bread Cards from the Undistributed Items bag which s/ } \\
\text { he can distribute as s/he pleases. }\end{array}$ \\
\hline Bakery Employment & $\begin{array}{l}\text { Once Baker Bettie has been hired at the bakery s/he will } \\
\text { receive the Bakery Employment Card to signify her employ- } \\
\text { ment. This item cannot be owned by any other player. }\end{array}$ \\
\hline Water Well & $\begin{array}{l}\text { Ownership of the water well provides that player with } 10 \\
\text { Water Access Cards. }\end{array}$ \\
\hline
\end{tabular}




\section{Game Play}

Once it is clear that all students understand what each item is used for, I explain how the game is played. Game play will proceed with players taking turns (starting with St. Bernard and moving in a clockwise fashion). There are two types of actions that a player can make on his or her turn: attack or pass. The remaining types of actions a player can make, trading or building, can be made at any time regardless of whether it is that player's turn or not. Below is a description of each of the four types of action that can be made during the game. ${ }^{6}$

Pass

If a player does not wish to attack anyone then s/he can pass his or her turn to the next player.

\section{Attacking}

A player can choose to attack another player and, if the attack is successful, the attacking player takes every resource card in the defending player's possession. The success of an attack is determined by the attack rating of the players involved in the altercation. Most players begin the game with an attack rating of 1 , with the exceptions that Alexandra the Great has a rating of 4, Nefarious Ned 2, and St. Bernard 0. Players (except for St. Bernard) can increase their attacking by 1 if they have a spear in their possession. In order to successfully attack someone the attacking player must have an attack rating which is at least one greater than that of the defending player. For instance, if Player X has an attack rating of 2 and Player $Y$ has an attack rating of 1 then Player X could execute a successful attack against Player Y.

Additionally, one can increase his or her attack ability by enlisting the help of other players. For instance if Player Y (with an attack rating of 1) wanted to attack Player X (with an attack rating of 2) then Player $Y$ could make a deal with 2 other players who have an attack rating of 1 to collectively defeat Player X (by a score of 3-2). In response a player can defend him or herself by enlisting the help of other players to defend against the attacking group. Thus Player Y could fend off the attacking group formed by Player $\mathrm{X}$ by convincing one other player to join in his/her defense. In basic terms, whichever group ends up with the higher attack rating is the victor of that attack. If the attacker/ attacking group has the higher attack rating then whoever originally initiated the attack receives all of the other person's resources, and can redistribute them as s/he please. If the defender/defending group has the higher attack rating then whoever was originally attacked receives all the resources of the person who initiated the attack, and can re- 
distribute them as $\mathrm{s} / \mathrm{he}$ pleases. If the attacker(s) and defender(s) end up with the same attack rating then no resources are moved between players. One thing to note here is that there the strategy of deception and dishonesty is open to students. The person who initiates the attack may offer some compensation for others to assist him/her, but then once the attack is completed not follow up on the agreement, and keep all of the resources for him or herself. I don't make any mention of this possibility when explaining the rules, but instead allow students to consider for themselves whether this is a fruitful strategy.

Because a player who is the victim of a successful attack loses all of his/her items, this means that player will also lose his/her freedom and will be taken captive. When this happens there are special rules for players who hold others captive and those who are in captivity.

\section{Rules for Captors}

Once a player has taken another captive s/he is allowed to force that player to help attack or defend against other players. Additionally, a player who holds Baker Bettie captive can force her to work at the bakery, and Bertha the Builder and Blacksmith Betty can be forced to use their blacksmith and building skills if they are provided with the necessary lumber.

\section{Rules for Captives}

The only action which a captive can take is to try to convince other players to free him/her. This is done by attacking that player's captor according to the previous attacking rules, and the captive player can be a part of this attacking group. If the attack is successful then, just like before, the captive gains all of his/her former captor's resources and can distribute them as s/he pleases. Furthermore, having one's own freedom is a necessary condition of being able to own any resources. Consequently, captive players cannot receive "gifts" from other players.

\section{Trades}

Any player(s) can trade any items with another player(s).

\section{Building}

A player can use lumber to build spears, houses, and/or the bakery at any time during the game. Remember that only Blacksmith Bettie can build spears, and only Bertha the Builder can build the bakery, but that anyone can build a house. 


\section{Goals of Game Play}

After explaining the different moves which players can make I then explain the goals which each player has in playing the game. These goals are (1) survival and (2) to gain as much glory as possible. The conditions for meeting these goals are outlined below.

\section{Survival}

The following survival needs must be met by the end of the game or that player will die.

\section{Food}

A player must have at least one Apple Card, Bread Card, or Cow Card in order to have food to survive.

\section{Water}

A player must have at least one Water Access Card in order to have enough water to survive.

\section{Shelter}

A player must have either a House Card, a Church Residence Card, or the Church Card in order to have shelter to survive.

\section{Glory}

Inspired by Hobbes's reasons for conflict in the state of nature, every player has the goal of gaining as many items as possible in order to show his or her dominance over other players. ${ }^{7}$ To this end each item in the game will be assigned a certain number of glory points which will be added into a cumulative total at the end of the game. If a player has not met his or her survival needs then s/he will receive zero glory points. Glory points are assigned to items as follows.

\begin{tabular}{|l|c|}
\hline \multicolumn{1}{|c|}{ Item } & Glory Points \\
\hline Another Player's Freedom Card & 50 \\
\hline Bakery Card & 40 \\
\hline Church Card & 40 \\
\hline Water Well Card & 40 \\
\hline House Card & 25 \\
\hline Player's Own Freedom Card & 25 \\
\hline Cow Card & 15 \\
\hline Apple Card & 10 \\
\hline Bread Card & 10 \\
\hline Water Access Card & 5 \\
\hline
\end{tabular}




\begin{tabular}{|l|l|}
\hline Spear Card & 5 \\
\hline Church Residence Card & 5 \\
\hline Lumber Card & 1 \\
\hline Bakery Employment Card & 1 \\
\hline
\end{tabular}

\section{Ending the Game}

The game will continue in this fashion, with players attempting to gain resources by attacking others and trading, for a period of thirty minutes. Following this period of time the following steps will be taken.

(1) Players who have not met their survival needs will be pronounced "dead" and eliminated from the game. The items the dead players currently hold will also be removed from the game and placed in the Used Items bag.

(2) The remaining survivors will then vote on whether or not to enter civil society. In order to enter civil society all remaining players must vote in favor.

(2a) If the decision is made to enter civil society then the game ends and each player's final score is his or her total amount of glory points.

(2b) If the decision is made to not enter civil society then the game continues for another round of turns. At the completion of this round, steps (1) and (2) will be repeated.

This process can end in one of two ways. First, the game can end through a unanimous vote of the remaining players to enter civil society. Second, the game automatically comes to an end if there are three successive votes in which the decision is made to not enter civil society, signifying that the players have elected to stay in the state of nature. Players should be told that their decision should be based upon what decision will ultimately secure for them the most glory points. At this point something should also be said about the time frame of the game. The game works best in a seventy-five-minute time slot, where ten minutes can be spent on explaining the rules, forty-five minutes on playing (thirty minutes for the initial stage and fifteen for the ending), and twenty minutes for discussion. However, if the class period is only fifty minutes long, then the time allotted for playing should probably be cut to thirty total minutes (twenty minutes for the initial stage and ten for the ending), and the discussion saved for the following class. Once the game ends (whether civil society has been entered or not) students add up all the glory points they have attained, and whoever has the most points is the winner. 


\section{Explaining the Rules}

One of the challenges of using the game is explaining the rules to students. Although the game is actually quite simple and straightforward, and in my experience students often pick up the rules fairly quickly, students often seem initially intimidated when given the rule sheet. For this reason it is vital that the students have read the rules before coming to class. I usually make the rule sheet the assigned reading for that class day and inform them that there will be a short quiz over it at the beginning of class (which in my classes counts for one of their pop quiz grades). Then on the day of the game I go over the rules with the entire class reminding them that they can refer to the rule sheet during the game, and that I will be available to answer any questions.

At the outset of the game some students may be timid or unsure of how to proceed, but once a player initiates an attack play escalates very quickly. Players will negotiate (usually quite animatedly) for others to help them either attack or defend, and in subsequent turns alliances begin forming around control of key resources. From that point interaction between students and the instructor has only been necessary to answer any questions about the rules, and not to prompt students to participate.

\section{Discussion}

In broad terms, the game can be used to address two main questions that will likely have import throughout the course. (1) How does civil society come about? (2) Is the state of nature and the arrangement which arises from it fair? Below I discuss how the game can be used to address these questions.

\section{(1) How Does Civil Society Come About?}

For classes which are organized chronologically, one way to use the game is as a point of transition between ancient and modern political philosophy. For example, the game can help students see the different presuppositions which guide Aristotle and Hobbes. Each of these thinkers would give a very different answer to (1). Whereas Aristotle held that "man is by nature a political animal," Hobbes thought humans only gave up their freedom, and entered civil society, in mutually advantageous circumstances. Although this issue is central to political philosophy, many students have difficulty grasping what is at stake here because, ultimately, each thinker believes that we end up in the same place. The story each tells ends with us entering civil society. The question is simply whether this is best explained as a natural instinct in human beings, or whether political society must be imposed through artifice. The game can make help to make this seem- 
ingly abstract question more tangible. In addition to the choice at the end of the game regarding whether to enter civil society, players will inevitably come to cooperate with others throughout the course of the game. In discussion, have students consider what their motives were for doing so. Within the context of the game, of course, the reason in many cases is expediency and mutual self-advantage. Given this, students should then consider whether this challenges Aristotle's political naturalism. Specifically, students should consider whether the game accurately shows that people only cooperate when it is in their self-interest, or whether the game creates an artificially competitive environment that eschews our natural social/political instincts. By going through this exercise, students will be better able to understand what Aristotle means when he claims that political society is natural, and better prepared to understand the significance of Hobbes's claim that political society arises through self-interest. They can then see that each of these thinkers conceived of civil society as providing a resolution to a different type of problem: the satisfaction of a natural instinct in one case, and the regulation of conflict in the other.

Another way to approach this issue is to use the game as a device for getting students to think about human nature. The driving motivational force in the game, and what makes the game fun to play, is the competitive pursuit of glory. Conflict ensues as students employ, in many cases, "back-handed" tactics in order to secure the most resources for themselves. As a result, the game largely portrays the state of nature in the way Hobbes described, as "solitary, poore, nasty, brutish, and short." There are, however, some notable exceptions which can be useful for classroom discussion. Despite the fact that the game is set up to reward selfish behavior, in some cases students behave in ways that undermine their pursuit of the most glory points. Students at times will refrain from breaking an agreement even when it is in their best interest, or at the end of the game settle for a less than optimal personal outcome in order to cooperate with others. At minimum, some students will at least report feeling bad about double-crossing their classmates. It is helpful to have students discuss where such tendencies come from. From a Hobbesian point of view, the game takes away the normal societal constraints upon our behavior, thus allowing for expression of our natural selfishness. Any other-regarding tendencies are simply the residue of real-life social conditioning. Many students, however, are not so willing to cast aside their moral inclinations as artificial. This provides an excellent opportunity to contrast Hobbes with Rousseau who held that people are naturally good, but made more selfish by the institution of civil society. Here students can discuss whether it is the game's imposition of glory as the ultimate goal, rather than unrestrained human nature, which accounts for the rampant conflict in the game. Does the fact that moral consid- 
erations could not be eradicated, even in an environment purposefully constructed to promote unrestrained competition, show that compassion is more natural than selfish cunning? This prepares students to consider Rousseau's alternative view that we do not enter civil society to save us from the insecurity of the state of nature, but instead because of a historical progression stemming from the institution of property. This is an institution which, in his view, has lead to "many crimes, wars, and murders," and not saved us from them by initiating the move away from our natural condition. ${ }^{10}$ Discussion of this point can also be helpful for later discussions of Marx's critique that the competitive nature of capitalism alienates us from authentic human nature. ${ }^{11}$

There is one last area of discussion regarding question (1): can pure self-interest lead to the establishment of civil society? Inherent to Hobbes's account is the idea that civil society arises once we realize that cooperation is in our own self-interest. Thus, our natural egoism does not prevent construction of the great "Leviathan." The game, however, can provide reason to question this idea that is expressed in the following passage from Hume.

But, in order to form society, it is requisite not only that it be advantageous,
but also that men be sensible of these advantages; and it is impossible, in their
wild uncultivated state, that by study and reflection alone they should ever
be able to attain this knowledge. Most fortunately, therefore, there is con-
joined to those necessities, whose remedies are remote and obscure, another
necessity, which, having a present and more obvious remedy, may justly be
regarded as the first and original principle of human society. This necessity
is no other than that natural appetite betwixt the sexes, which unites them
together, and preserves their union, till a new tie takes place in their concern
for their common offspring. ${ }^{2}$

Here Hume notes that in order to establish civil society it is not sufficient for it to merely be advantageous, but it must also be recognized as such. Yet if the advantages of civil society are to be recognized, then people cannot be motivated purely by self-interest and the pursuit of glory. In Hume's view, these pursuits only blind us to the future consequences of our actions. For this reason there must also be some natural ties of affection among people. This point is made nicely by the ending of the game. If players are motivated purely by gaining as many glory points as possible, then the only person whose interest it is to enter civil society is whoever currently has the most points. All other players will have incentive to continue the game in order to overtake whoever has the most points (since the opportunity to gain glory is abolished by entering civil society). However, what often happens is that players agree to end the game even when doing so ensures that they will end the game with the most points. There are multiple reasons why this may occur. In some cases players simply become satisfied 
with a lesser amount of points, or perhaps simply grew weary of the uncertainty that comes with each turn. In some cases, however, the decision is made for the reasons outlined by Hume. Students explain that they chose to enter civil society because of the concern they had for the well-being of the other players interrupted their pursuit of selfinterest. In any case, the very fact that players choose to enter civil society (as they generally do) shows that, for whatever reason, pursuit of maximal self-interest must be placed aside.

(2) Is the State of Nature and the Arrangement which Arises from it Fair?

One of the first questions I ask following the game is "who thought this game was fair?" Generally about half of the game's participants fail to meet their survival needs and "die" after completion of the game's first phase. These students immediately respond that the game was not fair at all. The character St. Bernard is the paradigmatic example of why. This character has an attack rating of zero, which cannot be increased, and is immediately taken advantage of by other stronger players. Consequently, because St. Bernard cannot use the ability to help others attack as a bargaining chip s/he usually spends the game trying and failing to escape captivity.

The intuition many students have that the game is unfair can help contrast Hobbes's view that "nothing can be unjust" in the state of nature, ${ }^{13}$ with Locke's view that even in this pre-societal condition "no one ought to harm another in his life, health, liberty, or possessions." 14 Such intuitions about fairness can also help prepare students to discuss Rawls later in the course by seeing the role that chance and fortune play in one's success. One of the take away points from "The Locke Game," by Immerwahr et al., is that one's success in the game is, to a significant extent, determined by how one begins the game. In "The Locke Game" one either plays as a "native" or a "colonist," where the latter has considerable advantages. My game furthers this idea in a number of ways. First, there is even more differentiation among the players insofar as each student is assigned his or her own specific character. This forces students to form a strategy that will be successful for their specific situation, and consequently realize how difficult it may be to overcome certain weakness. Second, the game also incorporates the influence of fortuitous chance in another way. Many times a player's success is largely dependent upon the order of turns (which determines who gets the first chance to initiate an attack), or where certain players are sitting in relation to one another (which often determines how alliances form). I make the point here that in the state of nature one's chances for success may very well depend upon the random occurrence of disease, natural disasters, or other hardships. As Immerwahr et al. also noted with their game, there is generally disagreement about the 
fairness of the game. ${ }^{15}$ Some students argue that success in the game comes through shrewd decision making and strategy, while others hold that (because of the influence of fortune) the plight of those unable to meet their survival needs was unfair.

This discussion prepares students for covering Rawls later in the course. Students are often puzzled at first why Rawls makes use of the abstract original position with its actors behind the veil of ignorance, and often fail to see what benefits it can have for deriving a conception of justice. By playing the game, students can have a greater understanding of why Rawls seeks to "[exclude] knowledge of those contingencies which set men at odds and allow them to be guided by their prejudices." 16 After having gone through this exercise students understand that the veil of ignorance is meant to eliminate bias and prevent the seemingly unfair treatment which they (or their classmates) suffered during the game.

\section{Conclusion}

Ultimately, I think the game is effective not only for the philosophical points it makes, but for how it makes them. These points could, of course, be covered solely in a lecture format. Yet by giving students an actual experience of the dynamics involved in the state of nature students come away with a deeper understanding of many of the problems and themes prevalent in political philosophy. ${ }^{17}$ As a consequence, future class discussions are enriched because students have personal experience to reflect upon and respond to. The state of nature is no longer merely a philosophical abstraction, but an idea to which students can now relate with more concrete experience.

\section{Notes}

A previous version of this game was presented at the Nineteenth International ConferenceWorkshop on Teaching Philosophy at St. Edwards University in Austin, Texas, July 25-29, 2012. I benefited from a number of useful suggestions made by those who participated in the session. I also received a great deal of helpful feedback from many of my colleagues who played the game, helped me administer the game, or used it in their own classes, and from many of my own students. Finally, I owe special thanks to David Agler, Deniz Durmus, Toby Svoboda, and an anonymous reviewer from Teaching Philosophy for reading previous versions of this paper.

1. For an example of a state of nature-style game, see John Immerwahr, "The Hobbes Game," Teaching Philosophy 1:4 (Fall 1976): 435-39, and, for discussion of this game, see Lee C. Archie, "An Analysis of 'The Hobbes Game,"” Teaching Philosophy, 18:3 (September 1995): 257-68. See also John Immerwahr, Sean McCann, Catherine Murphy, and Robert Zampetti, “The Locke Game,” Teaching Philosophy 6:1 (January 1983): 31-39, for his game intended for use with Locke's political philosophy (in particular his views of property), and M. W. Jackson, "Using the Locke Game," Teaching Philosophy 9:3 (September 1986): 253-54, for discussion of this game. See Christina M. Bellon, 
"At Play in the State of Nature: Assessing Social Contract Theory Through Role Play," Teaching Philosophy, 24:4 (December 2001): 315-24, for an example of a more open ended role-playing exercise corresponding to Hobbes's state of nature.

2. Immerwahr, "The Hobbes Game."

3. It should be noted that there is differentiation present in Immerwahr's "The Locke Game." Here, participants are assigned to play as either "natives" or "colonists," each of which has different capabilities. See Immerwahr et al., "The Locke Game."

4. Bellon, "At Play in the State of Nature."

5. As Bellon clearly states, her role-playing activity is "not a true game, and has no specified goal, final end state, or winner" (Bellon, "At Play in the State of Nature," 315). As such, there may be other pedagogical goals which are accomplished more effectively in such an open ended role playing exercise.

6. Another variation of the game is to get rid of turns and allow players to take actions at any time during game play. There are advantages and disadvantages of doing so. The primary advantage is that not using turns more closely models how the state of nature would operate, and increases the sense of insecurity, since any player can be attacked at any time. However, the main disadvantage of this setup (which I found from an outside-the-classroom dry run with some colleagues) is that the game becomes more disorganized. I am grateful for discussions with the participants at the Nineteenth International Conference-Workshop on Teaching Philosophy on the merit of using turns.

7. Thomas Hobbes, Leviathan, ed. J. C. A. Gaskin (New York: Oxford University Press, 1996), 83.

8. Aristotle, The Politics, in Aristotle: The Politics and the Constitution of Athens, ed. Stephen Everson (New York: Cambridge University Press, 1996), 1253a.

9. Hobbes, Leviathan, 84.

10. Jean-Jacques Rousseau, Rousseau: 'The Discourses' and Other Early Political Writings, ed. Victor Gourevitch (New York: Cambridge University Press, 1997), 164.

11. Karl Marx, Economic and Philosophic Manuscripts, "Alienated Labor," in Karl Marx: Selected Writings, ed. Lawrence H. Simon (Indianapolis: Hackett, 1994), 58-68.

12. David Hume, A Treatise of Human Nature, edited with Analytical Index by L. A. Selby-Bigge and text revised and notes by P. H. Nidditch, 2nd ed. (Oxford: Clarendon, 1978), 486.

13. Hobbes, Leviathan, 85.

14. John Locke, Two Treatises of Government, ed. Peter Laslett (New York: Cambridge University Press, 1988), 271.

15. Immerwahr et al., "The Locke Game," 35.

16. John Rawls, A Theory of Justice (Cambridge, Mass.: Belknap Press of Harvard University Press, 2005), 19.

17. There is also some evidence that using games in the classroom can be beneficial by appealing to a wide range of learning styles. See Martin Gerwin, "The Hobbes Game, Human Diversity, and Learning Styles," Teaching Philosophy 19:3 (September 1996): 247-58, for a discussion of this point.

Ryan Pollock is a graduate assistant in the Department of Philosophy at Penn State University. He teaches classes in ethics, applied ethics, and social and political philosophy, and has research interests in early modern thought, especially David Hume's moral and political theory.rcp170@psu.edu 